Review Article

\title{
A Review on the Impacts of the Air Pollution on the public Health: A Case for Different Metropolises around the World
}

\author{
Zahra Asadi ${ }^{1}$, Nima Norouzi ${ }^{2, *}$ \\ ${ }^{1}$ Al-Ameen College of Pharmacy, Rajiv Gandhi University of Health Science (RGUHS), Bangalore, India \\ ${ }^{2}$ Department of energy engineering and physics, Amirkabir university of technology (Tehran polytechnic), 424 \\ Hafez Avenue, PO. Box 15875-4413, Tehran, Iran \\ *Correspondence: n.nima1376@gmail.com
}

How to cite this paper: Asadi, Z., \& Norouzi, N. (2021). A Review on the Impacts of the Air Pollution on the public Health: A Case for Different Metropolises around the World. Current Research in Public Health, 1(1), 13-22. Retrieved from https://www.scipublications.com/journal/index.php/crph/article/view/92

Received: July 12, 2021

Accepted: August 20, 2021

Published: August 21, 2021

Copyright: (c) 2021 by the authors Submitted for possible open access publication under the terms and conditions of the Creative Commons Attribution (CC BY) license (http://creativecommons.org/licenses /by/4.0/).

\begin{abstract}
Air pollution is currently considered a global problem in both developing and developed countries. Substances that invade our spaces are components of air pollution that cause a strong negative impact on health for those who are exposed, not only in the cardiovascular and respiratory systems but are being related to the etiology of pathologies throughout the body, with a decrease in life expectancy and even an increase in mortality and alterations of the genetic material. This literature review aims to collect employing a search the implications that the components of air pollution have on the health of those exposed, from a clinical and molecular point of view. For the search, the DeCS descriptors created by BIREME were used: air pollution, cardiovascular system, respiratory diseases. The following databases were consulted: PubMed, ScienceDirect, and Scopus. The search criteria considered the year of publication and whether the original language was English or Spanish. It was concluded that the study of the different particles and the consequences that exposure to them entails is of vital importance for the development of control, prevention, and treatment mechanisms; since they can generate pathologies that range from something as tangible as lung diseases and occlusive heart disease to epigenetic changes that affect health.
\end{abstract}

Keywords: Air pollution; cardiovascular diseases; respiratory diseases; Air pollution.

\section{Introduction}

Air pollution is a global problem, affecting all countries regardless of their level of development. It can occur in outdoor environments, in which case the industry and massive vehicle load are the main associated factors, and indoors, where the main pollutant is cigarettes [1,2]. So much so that in a study carried out in Medellín in Colombia, a cyclical variation of the levels of pollutants during the day was found, which are greater in hours of the morning and afternoon, being this corresponding to the hours of high traffic in the city [3].

This pollution is made up of a varied amount of substances such as carbon monoxide $(\mathrm{CO})$, carbon dioxide $\left(\mathrm{CO}_{2}\right)$, ozone $\left(\mathrm{O}_{3}\right)$, sulfur dioxide $\left(\mathrm{SO}_{2}\right)$, nitrogen dioxide $\left(\mathrm{NO}_{2}\right)$, volatile organic compounds, and material Particulate (PM), a fine mixture of liquid and solid products, classified according to their diameter is less than 10 microns (PM10), less than 2.5 microns (PM2.5), less than one micron (PM1) and even in PM extra-fine less than 0.1 microns [4-6]. The problem generated by the presence of these pollutants in inhabited environments is their deleterious impact on the health of those exposed [1,7].

More evidence of this association emerges; it has even been shown that people who reside in clearly contaminated urban areas have 1.7 times more respiratory diseases than those who live in rural areas [8]. Likewise, it was found that contact with PM is related to acute infections of the lower respiratory tract, elevation of C-reactive protein, and alterations of the coagulation system, which increase the susceptibility to thrombotic events [911]. 
The duration of exposure to pollutants is another relevant aspect that can lead to different presentations, as shown by a study carried out in Los Angeles that found for the first time a relationship between long-term exposure and thickening of the intima and the carotid media. This reason suggests an environmental etiology for atherosclerosis [12]. At the same time, a Canadian study found a greater association between short-term exposure and the development of stroke [13].

\section{Materials and Methods}

The search for articles was carried out considering the following medical descriptors consulted in DeCS created by BIREME: air pollution, cardiovascular system, and respiratory diseases. The following databases were consulted: PubMed, ScienceDirect, and Scopus. The search criteria considered the year of publication and whether the original language was English or Spanish. One hundred fifty-seven articles were obtained, of which 63 were selected for writing the review.

\section{Clinical aspects of exposure to environmental pollution}

Due to scientific concern about growing air pollution and the appearance of smog over large cities, it began more than 50 years ago to study the relationship that exposure to air pollution and the deterioration of health can have, which has allowed us to demonstrate that the respiratory and cardiovascular systems are mainly affected [14]. (See Table 1)

Table 1. Impact of environmental pollution on the different systems

\begin{tabular}{|c|c|c|}
\hline System & Impact & Associated pollutants \\
\hline $\begin{array}{l}\text { Cardiovas- } \\
\text { cular }\end{array}$ & $\begin{array}{l}\text { Cardiovascular morbidity and mortality. } \\
\text { Development of: heart failure, sudden death, ar- } \\
\text { rhythmias, peripheral arterial disease, and hy- } \\
\text { pertension. } \\
\text { Ischemic events. }\end{array}$ & $\begin{array}{c}\mathrm{PM}_{2,5}, \mathrm{PM}_{10} \text { and PM-ul- } \\
\text { trafine } \\
\mathrm{NO}_{2} \\
\mathrm{SO}_{2}\end{array}$ \\
\hline Pulmonary & $\begin{array}{l}\text { Mortality due to respiratory causes. } \\
\text { Development of lung cancer. } \\
\text { Hospital admission for respiratory causes. } \\
\text { Chronic obstructive pulmonary disease } \\
\text { Acute lower respiratory infections }\end{array}$ & $\begin{array}{l}\mathrm{PM}_{2,5}, \mathrm{PM}_{10} \\
\mathrm{NO}_{2} \\
\mathrm{SO}_{2} \\
\mathrm{O}_{3} \\
\mathrm{DEP}\end{array}$ \\
\hline Other effects & $\begin{array}{c}\text { Alterations in fetal development. } \\
\text { Insulin resistance. } \\
\text { Gastrointestinal disorders. }\end{array}$ & $\begin{array}{c}\mathrm{PM}_{2,5}, \mathrm{PM}_{10} \\
\mathrm{SO}_{2} \\
\mathrm{PAH}\end{array}$ \\
\hline
\end{tabular}

\subsection{Impact at the cardiovascular level}

In 2004, the American Heart Association (AHA) published its first publication mentioning the relationship between air pollution and cardiovascular disease. In this publication, it was concluded that short-term exposure could contribute to acute cardiovascular morbidity and mortality, and long-term was the cause of a decrease in life expectancy for 
a couple of years, inclusive, it was found that cardiovascular deterioration due to contamination can be more numerous than that caused by underlying respiratory diseases $[15,16]$.

Recently, a special emphasis has been placed on PM's implication as a cause of cardiovascular diseases since an uncountable number of its constituents can cause biological damage to this system. However, the component directly responsible is unknown, although it is considered that it must have an intrinsic reduction potential and the ability to trigger oxidative stress in cardiovascular tissue [17]. These changes alter the activity of the autonomic nervous system, the inflammatory process, the activity of endothelin-1, abnormal activation of platelets, the integrity of the vascular endothelium, which can lead to ventricular arrhythmias, decompensation of heart failure, and myocardial infarctions. , in other words, in an increased risk of cardiovascular mortality [18-20].

Most studies find a significant relationship between cardiovascular morbidity and mortality and the amount of PM2.5; in fact, the risk is increased by $1 \%$ for every $10 \mathrm{ug} / \mathrm{m} 3$ of PM2.5 present in the environment [5,21,22]. But in addition, contact with PM10 and PM-ultrafine has also been documented as a risk factor for developing cardiovascular diseases such as heart failure, sudden death, arrhythmias, peripheral arterial disease, and increased hospitalization for various cardiovascular causes [23,24].

There are still many questions to be resolved that require studies with strict methodological rigor since many triggered effects do not correspond simply to the addition of acute day-to-day effects, as is the case of atherosclerotic plaques, whose formation and instability are related to endothelial damage and vascular dysfunction secondary to PM, and for which a sequential process is required, not explained by acute exposure, and which in the long term is the cause of cardiac, cerebral and peripheral ischemic events. Additionally, it has been deduced that chronic PM2.5 can increase the risk of long-term cardiovascular events between $93 \%$ and $95 \%$ [17].

The relationship between PM and cerebrovascular disease has also been the subject of multiple studies that have identified PM2.5 as a cause of increased hospitalizations for this type of pathology, more related to values above PM10, especially in diabetic patients, elderly, and with concomitant coronary disease. Furthermore, the evidence linking cerebrovascular diseases, specifically ischemic attacks, with chronic contact to PM2.5, over acute contact, is more consistent [25]. Hypertension in children due to exposure to specific components of PM was the goal set by Bilenko et al. in 2015, who found a statistically significant relationship between the increase in systolic pressure and iron, silicon, and potassium in PM10 with silicon and iron in PM2.5 [26].

The ultra-fine molecules of PM that is, PM0.1, also constitute a cardiovascular risk since it has been discovered that they are capable of entering cells through non-phagocytic pathways and causing damage to the organelles, which added to the PM's intrinsic capacity to produce reactive oxygen species (ROS) represents significant damage to the lung and heart tissue. It can also activate the production of Natural Killer (NK) cells and interact with different receptors involved in the functioning of the immune system [25]. In addition to this, it accelerates atherosclerosis with suppression of the apo E gene demonstrated in mice due to the pro-oxidant substances that compose it [27].

The strong scientific evidence presented led the AHA to recognize that PM exposure is a modifiable factor that increases the risk of cardiovascular morbidity and mortality [25]

Despite this, PM is not the only concern, and a study carried out in European cities between 1990 and 1996 revealed a dangerous relationship between hospital admission for ischemic heart disease in people over 65 years of age and environmental pollution from $\mathrm{SO} 2$ [28]. On the other hand, although it has been reported that the effects of $\mathrm{NO}_{2}$ only aggravate the conditions of previously ill people, a strong relationship of this substance with fatal myocardial infarction was found, possibly due to the accelerating effect on the atherothrombotic process [21].

A study carried out in Rome looked for the relationship between the specific causes of death in the adult population and the environmental exposure to $\mathrm{NO}_{2}, \mathrm{PM} 2.5$, and 
proximity to vehicular traffic. Of the deaths that occurred during the study period (20012010), cardiovascular problems were responsible for $40 \%$ and were closely connected to contact with both $\mathrm{NO}_{2}$ and PM2.5, cerebrovascular causes corresponded to $4 \%$, which was demonstrated a significant relationship with PM2.5 but not with $\mathrm{NO}_{2}$, nor with the distance to vehicular traffic. The other causes of mortality were respiratory disease $(6 \%)$ and cancer $(8 \%)$ [29].

Other demographic factors have been studied. Curiously, a greater association was found between cardiovascular risk due to PM2.5 and populations with low educational levels and low socioeconomic status, a situation that divergent lifestyles can explain. Thus, habits, type of work, low fruit, and high-fat consumption predispose to obesity and cardiovascular diseases, which increases the susceptibility of this population [21,22,29].

Finally, some studies suggest greater susceptibility on the part of women, but this cannot be truthfully stated, and a larger study is required to prove it $[29,30]$. A study carried out in the United States identified that exposure to air pollution affects the thickness of the vascular intima and that it is different between ethnic groups, but a total trend was not found for one of the two sexes [31].

\subsection{Impact at the pulmonary level}

Due to the ease with which air pollutants can come into contact with the alveolar epithelium, they directly negatively impact respiratory function and the appearance of this system's diseases, symptoms, hospitalization, and emergency admissions. and its mortality [32,33].

Although air pollution is a problem worldwide, there is geographic variability in the presentation of respiratory diseases because highly polluted regions have a higher number of hospital admissions. A curious fact is that the elderly and children appear to be affected equally by pollution regardless of the geographic region in which they reside [34]. Suppose we refer to the topographic characteristics of the study city, Antioquia, because it is located in a valley surrounded by high-altitude mountains. In that case, it means that pollutants cannot be swept away by air currents, generating accumulation and, therefore, greater exposure [3].

A study was carried out in Bucaramanga, Colombia, to associate air pollution with the prevalence of symptoms indicative of asthma in preschool children. Although they identified that cigarettes and aerosols were the most common pollutants within the home, they did not find a statistically significant association [35]. Still, it would be interesting to consider this association with contaminants outside the home to see whether or not they represent a risk factor for the development of asthma.

Contaminants such as $\mathrm{PM}, \mathrm{O}_{3}, \mathrm{NO}_{2}$, Diesel exhaust-particles (DEP, for its acronym in English), $\mathrm{SO}_{2}$, polycyclic aromatic hydrocarbons ( $\mathrm{PAH}$, for its acronym in English), among others, have been the object of study in the field of pulmonology for several years now. In one of these studies, it was found that $\mathrm{NO}_{2}$ is involved in mortality from respiratory causes and both this and PM2.5 in the development of lung cancer, where each elevation of $10 \mu \mathrm{g}$ $/ \mathrm{m} 3$ increases mortality by $6 \%$ and mortality by $4 \%$. Possibility of developing lung cancer [36].

$\mathrm{O}_{3}$ seems to affect macrophage functionality, increasing the level of pro-inflammatory mediators, and stimulating ROS production, promoting tissue damage, and altering the production of pulmonary surfactant, by altering through epigenetic processes the encoding of the gene for surfactant type A protein (this being the most abundant of the pulmonary surfactant) which plays important roles in chemotaxis and phagocytic function of pulmonary macrophages [32,37].

In Tehran, $\mathrm{PM} 10$ and $\mathrm{NO}_{2}$ are above the values proposed by the $\mathrm{WHO}$, which has led to a greater negative impact on the health of this population, where $9.3 \%$ of mortality due to respiratory disease is attributed to $\mathrm{PM} 6.09 \%$ in hospital admission. $\mathrm{SO}_{3}$ and $\mathrm{O} 3$ have an estimated attributable share of respiratory mortality of 7.73 and $7 \%$, respectively [4]. 
Unfortunately for Colombia, there are little data on the characterization of particulate matter; One of the studies that talks about this were developed in Pamplona-Santander, finding PM2.5 from sulfate ions, which will be mentioned later as an epigenetic factor, and PM2.5 was also found in crystalline phases of different compounds such as $\mathrm{SiO}_{2}$ and $\mathrm{CaCO}_{3}$, all from the combustion of fossil fuels, reaffirming the role of industry and vehicles in contributing to air pollution [38]. Another study carried out in Cali, Colombia; proposes another very interesting source of contamination, this is a garbage dump, where they found that in the areas near the dump, they exceeded the $48 \%$ allowed values of methane and benzene to prevent health problems [39], thus posing the possibility that these landfills are another important source of contamination and promote the study of their association with the development of lung diseases.

In Latin America, in cities such as Mexico City, Sao Pablo, Rio de Janeiro, and Santiago de Chile, it was found that there is a relationship between low socioeconomic status and mortality from respiratory causes, among which chronic obstructive pulmonary disease (COPD) stands out. . In addition, both in Mexico City and Santiago de Chile, a relationship was found between concentrations of environmental PM10 and mortality from respiratory causes and lower respiratory infection in infants and children [40], so much so that exposure to smoke from the biomass is associated with a higher frequency of acute lower respiratory infections in children under five years of age, with COPD in women over 30 years of age, and less important with lung cancer in women under 30 years of age [41].

An important factor is the alteration of the inflammatory response, which generates an increased risk of respiratory infections, asthma, and COPD [32].

Martinelli et al. managed to identify the influence of DEP on health, where it increases the expression of interleukins 6 and 8 (pro-inflammatory) and downregulates the anti-inflammatory molecule CC16 (clear cell protein) [25]. For its part, PM stimulates the production of various vasoactive and pro-inflammatory mediators in lung cells, such as IL-6, IL-1 $\beta$, Tumor Necrosis Factor-alpha (TNF- $\alpha$ ), and interferon- $\gamma$, which increases epithelial damage. Lung disease and the risk of respiratory disease. It also influences the autonomic nervous system through interaction with pulmonary receptors [25].

Despite the similarity that Asia, Europe, and North America have in $\mathrm{PM}, \mathrm{SO}_{2}, \mathrm{NO}_{2}$, and $\mathrm{O}_{3}$, Asia leads the problem [34]. Studies in China have obtained an interesting series of results, showing that increases of $10 \mu \mathrm{g} / \mathrm{m}^{3}$ of PM2.5 are associated with a $12 \%$ increase in the risk of presenting lower acute respiratory infections and that these in turn increase in children exposed to cigarette smoke, which is represented by the increase in hospital admissions [10]. Other studies indicate that the risk of acute respiratory disease will increase 3 to 10 times for each quartile, increasing the pollution concentration of PM10, $\mathrm{O}_{3}$, $\mathrm{CO}$, and $\mathrm{SO}_{2}[33]$. This is particularly worrying for our city since the levels described in a study carried out in 2009 in Medellín, Colombia found that the levels are higher than those of European and Asian countries and above the safety ranges proposed by WHO [3].

\subsection{Other effects}

Although they are not part of the most studied effects, there are references in the literature regarding how contamination affects fetal development and conditions of the baby at birth. Among the most mentioned relationships are changes in birth weight, for which the increase of one quartile in $\mathrm{SO}_{2}$ concentrations implies a decrease of $2.99 \mathrm{~g}$ and those of $\mathrm{O}_{3}$ (especially in the first and second trimesters) decrease 2.72g. Exposure to PM10, PM2.5, and CO has also been associated with weight loss [42]. Exposure to PAH could also affect crossing the placental barrier, which is reflected in variations in head circumference, birth weight, and height [43]. An explanation that has been given and that supports the effect of PAH and PM10 is their relationship with alterations in placental mitochondria, which increases oxidative stress, which, as mentioned before, plays an important role in the imbalance of cellular functioning. [44]. 
A study that sought to look for the implication of air pollution in insulin resistance or type 2 diabetes found a significant increase $(17 \%)$ in the development of insulin resistance when comparing exposure to $\mathrm{NO}_{2}$ and PM10. In addition to the above, the study concluded that children who had never moved from birth to age ten and who live within 500 meters of the main road are at greater risk of developing insulin resistance. The associated physiological mechanism is believed to have to do with $\mathrm{NO}_{2}$ 's ability to oxidize low-density lipoproteins (LDL), hinder their metabolism, and promote their accumulation [45]. The same situation was found with gestational diabetes and pre-eclampsia since exposure to $\mathrm{NO}_{2}$ during the first pregnancy was discovered as a risk factor for developing both diseases. However, other simultaneous factors can precipitate its geneses, such as smoking and educational level $[46,47]$. The negative effects do not stop there; gastrointestinal disorders have been described as a consequence of swallowing particles swept by the mucociliary purification systems of the respiratory tract. This may worsen previous gastrointestinal problems or be the etiology of new digestive disorders [48].

\subsection{Epigenetic alterations related to environmental pollution}

Epigenetic modification implies a link between the environment and genetic material alterations, suggesting that cellular information is heritable and modifiable and can lead to disease [49-51]. These phenomena are necessary processes for cellular functions and involve multiple mechanisms; the most studied is DNA methylation[52.53].

Precisely this has been the subject of multiple studies that have managed to demonstrate its relationship with exposure to environmental pollutants such as PM10, polycyclic aromatic hydrocarbons, black carbon, and sulfates. These alterations in DNA methylation may depend on other factors such as the duration of exposure to these pollutants, exposure to other substances, route of exposure, host factors, and previous genetic determinants [54-59].

Histone modification and other epigenetic mechanisms can regulate gene expression in conjunction with DNA methylation. The carboxyl ends of histones have specific amino acids sensitive to post-translational changes, thus modifying the histone configuration. These changes include methylation, acetylation, phosphorylation, sumoylation, and ubiquitination [60,61]. Exposure of human airway epithelial cell lines to PM10 induces acetylation in histone $\mathrm{H} 4$, increasing the expression of the widely known promoter genes for Interleukin 8 (IL-8) and the enzyme cyclo-oxygenase2(COX2) and studied for its pro-inflammatory activity $[62,63]$.

As they have been allowed to identify several studies that conclude that exposure to diesel vehicle emissions particles causes alteration in the expression of micro RNA (miRNA) in epithelial cells of the human airway grown in vitro in media with an air-liquid interface; this miRNA is associated with inflammatory response pathways [46, 64, 65]. Furthermore, heterochromatin formation can be mediated through interactions between intergenic noncoding RNAs and chromatin remodeling complexes, resulting in the expression of silencing genes [66,67].

\section{Discussion}

Dominici et al. found that hospital admissions for heart and lung disease with exposure to particulate matter increased slightly for both diseases when exposed to PM2.5 [23]. Later, in another study carried out by Keebaugh et al., they showed that by removing the organic component of the particulate material, the size and lipid content of the atherosclerotic plaques decreased, reducing oxidative stress and cardiovascular variability; thus supporting the premise that particulate matter behaves as a variable that increases the risk of cardiovascular disease, negatively impacting morbidity and mortality [27].

A meta-analysis that documented the total effect of the increase in PM10 on general mortality by Romieu et al. yielded important data with a statistically significant increase 
in mortality from cardiopulmonary disease by $0.94 \%$, respiratory $1.19 \%$, cardiovascular $0.72 \%$, cerebrovascular $1.10 \%$, and chronic obstructive pulmonary disease $2.44 \%$ [40]. Similarly, Liu et al. showed that the more polluted the person resided, the more hospital visits increased due to respiratory diseases with $p<0.0001$ [34]. Finally, and supporting the other studies mentioned, Santus et al. found that for each increase in an interquartile of the contamination level, the risk of admission to the emergency room for upper respiratory tract infection increased from $3 \%$ to $10 \%$ and similarly for exacerbation of the chronic obstructive pulmonary disease. These three large studies support the fact that environmental pollution does increase the risk of lung diseases requiring medical attention, even more than cardiovascular disease [33].

Other effects found in the literature review were the impact of air pollution on fetal development and pregnancy. Geer et al. found that high exposure to $\mathrm{SO}_{2}$ and $\mathrm{O}_{3}$ were associated with low birth weight. However, exposure to PM2.5 and PM10 was significantly associated with high birth weight [42]. On the other hand, Al-Saleh et al. showed significant changes in the decrease in head circumference, weight, and height at birth [43]. This gives rise to new research projects to deepen and clarify the effect that exposure to different environmental agents of pollution could have on the normal development of pregnancy and fetal variables.

Currently, epigenetic processes encompass different mechanisms, ranging from DNA methylation, histone, and micro RNA modification. These same processes have been studied under the influence of the environmental factor and whether or not these factors are inducers of said processes [52]. To this day, it is known that pathogenesis not only depends on the mutagenic capacity of environmental factors but that in their absence, epigenetics can be the etiological center of biological alterations [50]. In this way, the study and identification of the epigenetic processes involved in developing diseases due to continuous exposure to environmental agents caused by pollution will allow the future development of molecular markings that will open the doors to an earlier and later diagnosis, both timely interventions.

\section{Conclusions}

Air pollution is part of a series of complex mechanisms that alter the dynamics of the body and negatively impact health. It is from the most basic levels of the conformation of the genetic material that deleterious changes occur in the cell, and from there, multiple systems are affected, causing disease. Studying the different particles and the consequences of exposure to them is vital for the development of control, prevention and treatment mechanisms.

\section{Supplementary Materials: “Not applicable."}

Author Contributions: "Conceptualization, NNand ZA; methodology, ZA; software, NN; validation, $\mathrm{NN}$ and $\mathrm{ZA}$; formal analysis, NN; investigation, ZA; resources, NN; data curation, ZA; writing-original draft preparation, $\mathrm{NN}$; writing - review and editing, $\mathrm{NN}$; visualization, $\mathrm{NN}$; supervision, NN; project administration, NN; All authors have read and agreed to the published version of the manuscript."

Funding: "This research received no external funding."

Data Availability Statement: There is no associated data for this paper.

Acknowledgments: "No support and funding were used in this research."

Conflicts of Interest: “The authors declare no conflict of interest."

\section{References}

[1] Santos, U.P.; Garcia, M.L.; Braga, A.L.; Pereira, L.A.; Lin, C.A.; de André, P.A.; et al. association between traffic air pollution and reduced Forced Vital Capacity: A Study Using Personal Monitors for Outdoor Workers. PLoS One 2016;11(10):e0163225. 
[2] Pacheco, S.A.; Torres, V.M.; Louro, H.; Gomes, F.; Lopes, C.; Marçal, N.; et al. Effects of occupationalexpo- sure to tobaccosmoke: isthere a linkbetwee- nenvironmentalexposure and disease? J Toxicol Environ Health A 2013 ; 76(4-5):311-27.

[3] Bedoya, J.; Martínez, E. Calidad del aire en el Valle de Aburrá Antioquia -Colombia. Dyna 2009;76 (158):7-15.

[4] Naddafi, K.; Hassanvand, M.S.; Yunesian, M.; Momeniha, F.; Nabizadeh, R.; Faridi, S.; et al. Health impact as- sessment of air pollution in megacity of Tehran; Iran. Iranian J Environ Health SciEng 2012; 9(1): 28.

[5] Pope, CA 3rd; Dockery, D.W. Health effects of fine particulate air pollution: lines that connect. J Air Waste Manag Assoc 2006;56(6):709-42

[6] Touri, L.; Marchetti, H.; Sari-Minodier, I.; Molinari, N.; Chanez, P. The airport atmospheric environ- ment: respiratory health at work. Eur Respir Rev 2013;22(128):124-30.

[7] Katzung, B.G.; Masters, S.B.; Trevor, A.J. Basic \& Clinical Pharmacology. 12th ed. New York; NY: McGraw-Hill; 2012.

[8] Rizwan, S.; Nongkynrih, B.; Gupta, S.K. Air pollution in Delhi: Its Magnitude and Effects on Health. Indian J Community Med 2013;38(1):4-8

[9] Strak, M.; Hoek, G.; Godri, K.J.; Gosens, I.; Mudway, I.S.; van Oerle, R.; et al. Composition of PM affects acute vascular inflammatory and coagulative markers - the RAPTES project. PLoS One 2013;8(3):e58944.

[10] Mehta, S.; Shin, H.; Burnett, R.; North, T.; Cohen, A.J.Ambient particulate airpollution and acute lower respiratory infections: a systematic review and implications for estimating the global burden of disease. Air QualAtmos Health 2013; 6(1): 69-83.

[11] Li, Y.; Rittenhouse-Olson, K.; Scheider, W.L.; Mu, L. Effect of particulatematter air pollution on C-re- activeprotein: areview of epidemiologicstudies. Rev Environ Health 2012; 27(2-3):133-49.

[12] Künzli, N.; Jerrett, M.; Mack, W.J.; Beckerman, B.; La- Bree, L.; Gilliland, F.; et al. Ambient air pollution and atherosclerosis in Los Angeles. Environ Health Perspect 2005;113(2):201-6.

[13] Johnson, J.Y.; Rowe, B.H.; Allen, R.W.; Peters, P.A.; Ville- neuve, PJ A case-control study of medium-term exposure to ambient nitrogen dioxide pollution and hospitalizationfor stroke. BMC Public Health

[14] Brunekreef, B.; Holgate, S.T. Air pollution and health.Lancet 2002; 360(9341):1233-42.

[15] Brook, R.D.; Rajagopalan, S.; Pope, CA 3rd; Brook, J.R.; Bhatnagar, A.; Diez-Roux, A.V.; et al. American Heart Association Council on Epidemiology and Prevention; Council on the Kidney in Cardiovascular Disease; and Council on Nutrition; Physical Activity and Metabolism. Particulate matter air pollution and cardiovascular disease: An update to the scientific statement from the American Heart Association. Circulation 2010; 121(21):2331-78.

[16] Orru, H.; Laukaitienè, A.; Zurlyte, I. Particulate air pollution and its impact on health in Vilnius and Kaunas. Medicina (Kaunas) 2012; 48(9):472-7.

[17] Brook, R.D. Cardiovascular effects of air pollution. ClinSci (Lond) 2008; 115(6):175-87.

[18] O’Donnell, M.J.; Fang, J.; Mittleman, M.A.; Kapral, M.K.; Wellenius, G.A. Investigators of the Registry of Canadian Stroke Network. Fine particulate air pollution (PM2.5) and the risk of acute ischemic stroke. Epidemiology 2011; 22(3):422-31.

[19] Nasser, Z.; Salameh, P.; Nasser, W.; Abou Abbas, L.; Elias, E.; Leveque, A. Outdoor particulate matter (PM) and associated cardiovascular diseases in the Middle East. Int J Occup Med Environ Health 2015; 28(4):641-61.

[20] Finch, J.; Conklin, D.J. Air Pollution-Induced Vascular Dysfunction: Potential Role of En- dothelin-1 (ET-1) System. CardiovascToxicol 2016;16(3):260-75

[21] Hoek, G.; Krishnan, R.M.; Beelen, R.; Peters, A.; Ostro, B.; Brunekreef, B.; et al. Long-term air pollution exposure and cardiorespiratory mortality: a review. Environ Health 2013; 12(1):43.

[22] Chen, B.C.; Luo, J.; Hendryx, M. Zinc compound air releases from Toxics Release Inventory facilities and cardiovascular disease mortality rates. En- viron Res 2015; 142:96-103.

[23] Dominici, F.; Peng, R.D.; Bell, ML; Pham, L.; McDer- mott, A.; Zeger, S.L.; et al. Fine particulate air pollu- tion and hospital admission for cardiovascular and respiratory diseases. JAMA 2006; 295(10): 1127-34.

[24] Wang, C.; Tu, Y.; Yu, Z.; Lu, R. PM2.5 and Cardiovas- cular Diseases in the Elderly: An Overview. Int J Environ. Res Public Health 2015; 12(7):8187-8197.

[25] Martinelli, N.; Olivieri, O.; Girelli, D. Air particulate matter and cardiovascular disease: A narrative review. Eur J Intern Med 2013; 24(4):295-302.

[26] Bilenko, N.; Brunekreef, B.; Beelen, R.; Eeftens, M.; de Hoogh, K.; Hoek, G.; et al. Associations between particulate matter composition and childhood blood pressure - The PIAMA study. Environ Int 2015; 84:1-6.

[27] Keebaugh, A.J.; Sioutas, C.; Pakbin, P.; Schauer, J.J.; Mendez, L.B.; Kleinman, M.T. Is atherosclerotic di- sease associated with organic components of ambient fine particles? Sci Total Environ 2015; 533:69-75.

[28] Sunyer, J.; Ballester, F.; Tertre, AL; Atkinson, R.; Ayres, J.G.; Forastiere, F.; et al. The association of daily sulfur dioxide air pollution levels with hospital admissions for cardiovascular diseases in Europe (The Aphea-II study). Eur Heart J 2003; 24(8):752-60.

[29] Cesaroni, G.; Badaloni, C.; Gariazzo, C.; Stafoggia, M.; Sozzi, R.; Davoli, M.; et al. Long-term exposure to urban air pollution and mortality in a cohort of more than a million adults in Rome. Environ Health Perspect 2013; 121(3):324-31.

[30] Rosenlund, M.; Berglind, N.; Pershagen, G.; Hallqvist, J.; Jonson, T.; Bellander, T. Long-term exposure to urban air pollution and myocardial infarction. Epidemiology 2006; 17(4):383-90. 
[31] Jones, M.R.; Diez-Roux, A.V.; O’Neill, M.S.; Guallar, E.; Sharrett, A.R.; Post, W.; et al. Ambient air pollution and racial/ethnic differences in carotid inti- ma-media thickness in the Multi-Ethnic Study of Atherosclerosis MESA). J Epidemiol Community Health 2015; (12):1191-8.

[32] Silveyra, P.; Floros, J. Air pollution and epi- genetics: effects on SP-Aandinnate host de- fence in the lung. Swiss Med Wkly 2012; 2;142: w13579.

[33] Santus P; Russo A; Madonini E; Allegra L; Blasi F; Centanni S; et al. How air pollution influences clinical management ofrespiratory diseases. A case-crossover study in Milan. Respir Res 2012; 8(13):95

[34] Liu, H.Y.; Bartonova, A.; Schindler, M.; Sharma, M.; Be- hera, SN; Katiyar, K.; et al. Respiratory disease in relation to outdoor air pollution in kanpur; India. Arch Environ Occup Health 2013; 68(4):204-17.

[35] Rodríguez, L.; Rey, J.; Herrera, A.B. et al. Prevalencia de síntomas respiratorios indicativos de asma y asociación con contaminación atmosférica en preescolares de Bucaramanga; Colombia. Biomédica 2010; 0:15-22.

[36] Pope, CA 3rd; Burnett, R.T.; Thun, M.J.; Calle, E.E.; Krewski, D.; Ito, K.; et al. Lung cancer; cardio- pulmonary mortality; and long-term exposure to fine particulate air pollution. JAMA 2002; 287(9):1132-41.

[37] Vattanasit, U.; Navasumrit, P.; Khadka, M.B.; Kanitwit-hayanun, J.; Promvijit, J.; Autrup, H.; et al. Oxidative DNA damage and inflammatory responses in cultured human cells and in humans exposed to traffic-related particles. Int J Hyg Environ Health 2014; 217(1):23-33

[38] Quijano, A.; Quijano, M.J.; Henao, J.A. Caracterización fisicoquímica del material particuladofracción res- pirable PM2.5 en Pamplona-Norte de Santander- Colombia. Rev la Fac Ciencias 2010; 8(1):1-20.

[39] Gómez, R.M.; Filigrana, P.; Méndez, F. Descripción de la calidad del aire en el área de influencia del Botadero de Navarro; Cali; Colombia. Colombia Médica 2008; 39(3):245-252.

[40] Romieu, I.; Gouveia, N.; Cifuentes, L.A.; de Leon, A.P.; Junger, W.; Vera, J.; et al. HEI Health Review Committee. Multicity study of air pollution and mortality in Latin America (the ESCALA study). Res Rep Health EffInst 2012; 171:5-86.

[41] Alvis, N.; Hoz, F.D. La Contaminación del aire domiciliario y enfermedades respiratorias (in- fección respiratoria aguda baja; epoc; cáncer de pulmón y asma): evidencias de asociación. Rev Fac Med la niv Nac Colomb 2008; 56:54-64.

[42] Geer, L.A.; Weedon, J.; Bell, ML Ambient air pollu- tion and term birth weight in Texas from 1998 to 2004 . J Air Waste ManagAssoc 2012; 62(11): 1285-95.

[43] Al-Saleh, I.; Alsabbahen, A.; Shinwari, N.; Billedo, G.; Mashhour, A.; Al-Sarraj, Y.; et al. Polycyclic aromatic hydrocarbons (PAHs) as determinants of vari- ous anthropometric measures of birth outcome. Sci Total Environ 2013; 444:565-78.

[44] Janssen, B.G.; Munters, E.; Pieters, N.; Smeets, K.; Cox, B.; Cuypers, A.; et al. Placental mitochondrial DNA content and particulate air pollution during in utero life. Environ Health Perspect 2012; 120(9): 1346-52.

[45] Thiering, E.; Cyrys, J.; Kratzsch, J.; Meisinger, C.; Hoffmann, B.; Berdel, D.; et al. Long-term exposure to traffic-related air pollution and insulin re- sistance in children: results from the GINIplus and LISAplus birth cohorts. Diabetologia 2013; 56(8):1696-704.

[46] Malmqvist, E.; Jakobsson, K.; Tinnerberg, H.; Ri-gnell-Hydbom, A.; Rylander, L. Gestational diabe- tes and pre-eclampsia in association with air pollution at levels below current air quality guidelines. Environ Health Perspect 2013; 121(4): 48893.

[47] Bobak, M. Outdoor air pollution; low birth weight; and prematurity. Environ Health Perspect 2000; 108(2):173-6.

[48] Kish, L.; Hotte, N.; Kaplan, G.G.; Vincent, R.; Tso, R.; Gänzle, M.; et al. Environmental particulate matter induces murine intestinal inflammatory responses and alters the gutmicrobiome. PLoS One 2013; 8(4):e62220.

[49] Ji, H.; Khurana Hershey, G.K. Genetic and epigene- tic influence on the response to environmental particulate matter. J Allergy ClinImmunol 2012; 129(1):33-41.

[50] Stein, R.A. Epigenetics and environmental exposu- res. J Epidemiol Community Health 2012; 66:8-13

[51] Hochedlinger, K.; Blelloch, R.; Brennan, C.; Yamada, Y.; Kim, M.; Chin, L.; et al. Reprogramming of a mela- noma genome by nuclear transplantation. Genes Dev 2004; 18:1875-85.

[52] Baccarelli, A.; Bollati, V. Epigenetics and environ- mental chemicals. Curr Opin Pediatr 2009; 21(2): $243-51$.

[53] Rossella, F.; Polledri, E.; Bollati, V.; Baccarelli, A.; Fus-tinoni, S. Development and validation of a gas chromatography/mass spectrometry method for the assessment of genomic DNA methylation. Rapid Commun Mass Spectrom 2009; 23(17):263746.

[54] Vaduganathan, M.; Palma, G.De.; Manerba, A.; Goldoni, M.; Triggiani, M.; Apostoli, P.; et al. Risk of Cardiovas- cular Hospitalizations from Exposure to Coarse Particulate Matter ( PM10 ) Below the European Union Safety Threshold. Am J Cardiol- Elsevier In; 2016; 117(8):1231-5

[55] Madrigano, J.; Baccarelli, A.; Mittleman, M.A.; Wright, R.O.; Sparrow, D.; Vokonas, P.S.; et al. Prolonged ex- posure to particulate pollution; genes associated with glutathione pathways; and DNA methylation in a cohort of older men. Environ Health Perspect 2011; 119:977-82.

[56] Sánchez-Guerra, M.; Pelallo-Martínez, N.; Díaz-Barriga, F.; Rothenberg, S.J.; Hernández-Cadena, L.; Fauge- ron, S.; et al. Environmental polycyclic aromatic hydrocarbon (PAH) exposure and DNA damage in Mexican children. Mutat Res 2012; 742(1-2): 66-71. 
[57] Avanello, S.; Bollati, V.; Pesatori, A.C.; Kapka, L.; Bolog- nesi, C.; Bertazzi, P.A.; et al. Global and gene-specific promoter methylation changes are related to anti-B[a] PDE-DNA adduct levels and influence micronuclei levels in polycyclic aromatic hydro- carbon-exposed individuals. Int J Cancer 2009; 125:1692-7.

[58] Baccarelli, A. Breathe deeply into your genes genetic variants and air pollution effects. Am J Respir Crit Care Med 2009; 179(6):431-2.

[59] Tarantini, L.; Bonzini, M.; Apostoli, P.; Pegoraro, V.; Bollati, V.; Marinelli, B.; et al. Effects of particulate matter on genomic DNA methylation content and iNOS promoter methylation. Environ Health Perspect 2009; 117:217-22.

[60] Raisner, R.M.; Hartley, P.D.; Meneghini, M.D.; Bao, M.Z.; Liu, C.L.; Schreiber, S.L.; et al. Histone variant H2A.Z marks the 59 ends of both active and inactive genes in euchromatin. Cell 2005; 123:233-48.

[61] Goldberg, A.D.; Banaszynski, L.A.; Noh, KM; Lewis, P.W.; Elsaesser, S.J.; Stadler, S.; et al. Distinct factors con- trol histone variant H3.3 localization at specific genomic regions. Cell 2010; 140:678-91.

[62] Gilmour, P.S.; Rahman, I.; Donaldson, K.; MacNee, W. Histone acetylation regulates epithelial IL-8 release mediated by oxidative stress from en- vironmental particles. Am J Physiol Lung Cell MolPhysiol 2003; 284:L533-40.

[63] Cao, D.; Bromberg, P.A.; Samet, J.M. COX-2 expres- sion induced by diesel particles involves chro- matin modification and degradation of HDAC1. Am J RespirCell Mol Biol 2007; 37:232-9.

[64] Bollati, V.; Marinelli, B.; Apostoli, P.; Bonzini, M.; Nordio, F.; Hoxha, M.; et al. exposure to metal-rich particulate matter modifies the expression of candidate mi- croRNAs in peripheral blood leukocytes. Environ Health Perspect 2010; 118:7638.

[65] Jardim, MJ; Fry, R.C.; Jaspers, I.; Dailey, L.; Diaz-Sán- chez D. Disruption of microRNA expression in human airway cells by diesel exhaust particles is linked to tumorigenesis-associated pathways. Environ Health Perspect 2009; 117:1745-51.

[66] Noonan, E.J.; Place, RF; Pookot, D.; Basak, S.; Whitson, J.M.; Hirata, H.; et al. miR-449a targets HDAC-1 and induces growth arrest in prostate cancer. Onco- gene 2009; 28:1714-24.

[67] Ji, H.; Ehrlich, L.I.; Seita, J.; Murakami, P.; Doi, A.; Lindau, P.; et al. Comprehensive methylome map of lineage commitment from haematopoietic progenitors. Nature 2010; 467:338-42. 